\title{
GMDS Gene
}

National Cancer Institute

\section{Source}

National Cancer Institute. GMDS Gene. NCI Thesaurus. Code C114601.

This gene is involved in the metabolism of nucleotide-sugar complexes. 